\title{
Daya Saing dan Posisi Sektor Pangan IndonesiaMenghadapi Regional Comprehensive Economic Partnership (RCEP)
}

\section{Competitiveness and Position of the Indonesian Food Sector Towards Regional Comprehensive Economic Partnership (RCEP)}

\author{
Dadan Adi Nugraha, Minar Ferichani, dan Joko Sutrisno \\ Program Studi Magister Agribisnis, Program Pascasarjana Universitas Sebelas Maret \\ Jln. Ir Sutami 36 Kentingan Jebres, Surakarta, Jawa Tengah 57126 \\ Email: dadannugraha@pertanian.go.id
}

Diterima: 3 Januari 2020

Revisi : 4 Maret 2020

Disetujui : 17 April 2020

\begin{abstract}
ABSTRAK
Tulisan ini bertujuan mengetahui daya saing produk pangan Indonesia di negara mitra RCEP, mengetahui daya saing produk pangan negara mitra RCEP di Indonesia, serta mengetahui posisi produk pangan yang dapat dimanfaatkan dan perlu dilindungi dalam rangka kerja sama perdagangan bebas Regional Comprehensive Economic Partnership (RCEP). Daya saing produk pangan dianalisis menggunakan Constant Market Share Analysis (CMSA). Posisi sektor pangan yang dapat dimanfaatkan dan dilindungi diketahui dengan melakukan analisis terhadap kebijakan tarif dan nilai daya saing produk pangan. Data yang digunakan adalah data sekunder yang diperoleh dari United Nations Commodity Trade Statistics Database (UN Comtrade) dan Sekretariat ASEAN. Produk pangan Indonesia yang memiliki nilai daya saing positif di pasar negara mitra RCEP sebagian besar adalah produk pangan olahan seperti roti, biskuit, mie instan, pasta, margarin, dan minyak nabati. Sedangkan produk negara mitra RCEP yang memiliki daya saing di Indonesia teridiri dari produk pangan olahan dan segar seperti daging, beras, kacang, dan bawang putih. Posisi sektor pangan Indonesia dalam memanfaatkan kerja sama perdagangan RCEP adalah dengan mengusulkan penghapusan atau penurunan tarif produk pangan Indonesia yang berjumlah 23 produk di China, 5 produk di India, 16 produk di Jepang, dan 2 produk di Korea. Posisi sektor pangan Indonesia dalam melindungi sektor pangan dari liberalisasi perdagangan RCEP adalah dengan menerapkan kebijakan tarif untuk produk kategori sensitif yaitu beras dan gula.
\end{abstract}

kata kunci: daya saing, sektor pangan, RCEP

\section{ABSTRACT}

This study aims to know the competitiveness of the Indonesian food sector in the market of RCEP partner countries, the competitiveness of the food sector of RCEP partner countries in the Indonesian market, and the position of the food sector is facing RCEP trade liberalization. The analysis method used in this study is the Constant Market Share Analysis (CMSA). This study uses secondary data from UN Comtrade and the ASEAN Secretariat. Indonesian food products that have positive competitiveness in the markets of RCEP partner countries are mostly processed products such as bread, biscuits, instant noodles, pasta, margarine, and vegetable oil. RCEP partner countries that have competitiveness in the Indonesian market consist of processed and fresh food products such as meat, rice, beans, and garlic. The position of the Indonesian food sector in utilizing RCEP's trade cooperation is to propose the elimination of tariffs on Indonesian food products, and there are 23 products in China, five products in India, 16 products in Japan, and two products in Korea. The position of the Indonesian food sector in protecting the food sector from RCEP's trade liberalization is to implement tariff policies for sensitive categories of products such as rice and sugar.

keywords: competitiveness, food sector, RCEP

\section{PENDAHULUAN}

ertanian merupakan sektor strategis dalam menopang perekonomian nasional dan daerah. Hal ini terkait dengan kemampuan sektor ini dalam menyediakan bahan makanan, penghasil devisa, memberikan kesempatan kerja, dan sebagai pasar bagi produk produk industri (Juanda, 2001).

Indonesia merupakan negara agraris yang sebagian besar penduduknya berusaha di sektor 
pertanian. Jumlah petani di Indonesia pada tahun 2018 sekitar 33.487.806 jiwa. Anggota rumah tangga usaha pertanian pada tahun 2018 berjumlah 98.311.908 jiwa (BPS, 2018).

Menurut Daryanto (2009), sektor pertanian telah terbukti memiliki peranan penting bagi pembangunan perekonomian suatu bangsa. Hal ini berdasarkan pada kontribusi sektor pertanian yang tidak hanya berperan dalam pembentukan PDB, penciptaan kesempatan kerja, peningkatan pendapatan masyarakat dan perolehan devisa. Peranan sektor pertanian juga dapat dilihat secara lebih komprehensif, antara lain: (i) sebagai penyediaan pangan masyarakat yang mampu berperan secara strategis dalam penciptaan ketahanan pangan nasional (food security), yang sangat erat kaitannya dengan modal bagi pengembangan sektor-sektor lain (a net outflow of capital for invesment in other sectors); dan (vii) peran pertanian dalam penyediaan jasa-jasa lingkungan.

Sektor tanaman pangan sebagai bagian sektor pertanian merupakan sektor strategis dalam pembangunan perekonomian Indonesia. Namun kinerja perdagangan komoditas tanaman pangan menunjukkan neraca perdagangan masih bernilai negatif (Gambar 1). Nilai ekspor produk tanaman pangan jauh lebih kecil dibanding impornya. Namun demikian, impor produk tanaman pangan menunjukkan trend yang menurun, yaitu dari 7.519.027 (000 USD) tahun 2013 menjadi 6.491 .985 (000 USD) pada tahun 2017.

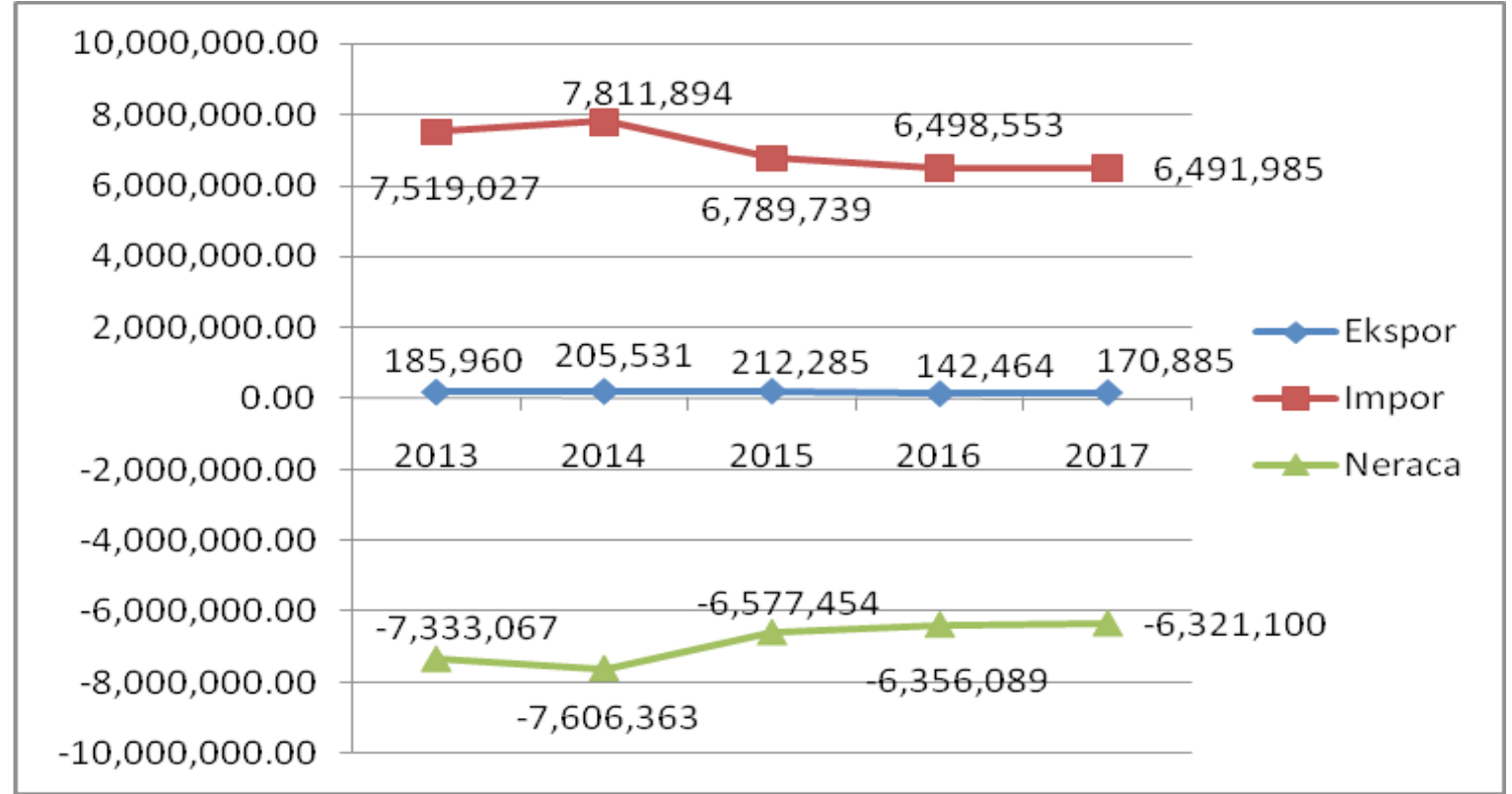

Sumber: Kementerian Pertanian (2018)

Gambar 1. Neraca Perdagangan Sektor Tanaman Pangan Indonesia (000 USD)

ketahanan sosial (socio security), stabilitas ekonomi, stabilitas politik, dan kemanan atau ketahanan nasional (national security); (ii) sektor pangan menghasilkan bahan baku untuk peningkatan sektor industri dan jasa; (iii) sektor pertanian dapat menghasilkan atau menghemat devisa yang berasal dari ekspor atau produk substitusi impor; (iv) sektor pertanian merupakan pasar yang potensial bagi produk-produk sektor industri; (v) transfer surplus tenaga kerja dari sektor pertanian ke sektor industri merupakan salah satu sumber pertumbuhan ekonomi; dan (vi) sektor pertanian mampu menyediakan
Keberhasilan perdagangan internasional suatu negara dapat dilihat dari daya saingnya. Daya saing merupakan konsep umum yang digunakan untuk merujuk pada komitmen persaingan pasar terhadap keberhasilan suatu negara dalam persaingan internasional (Bustami dan Hidayat, 2013).

Tingginya nilai impor produk tanaman pangan dikhawatirkan membuat ketergantungan terhadap produk impor semakin besar. Produk impor yang berharga murah dapat menurunkan daya saing produk dalam negeri. Lebih lagi, Indonesia saat ini sudah melakukan kerja sama 
perdagangan bebas bilateral maupun regional yang menghapus hambatan perdagangan.

Indonesia sudah tergabung dalam ASEAN menuju ASEAN Economic Community (AEC). ASEAN selanjutnya melakukan upaya integrasi global dengan menginisasi kerja sama RCEP. RCEP adalah sebuah bentuk kerja sama ekonomi dan perdagangan di kawasan ASEAN dengan enam negara mitra ekonominya, yakni: China, Jepang, Korea Selatan, India, Australia, dan Selandia Baru.

RCEP dibentuk sebagai upaya ASEAN mengharmonisasi sejumlah mekanisme perdagangan dengan enam mitra dagang ASEAN (Azhari dan Widyastutik, 2016). ASEAN sudah menjalin kerja sama dengan enam negara itu, yakni China, Jepang, Korea Selatan, India, Australia, dan Selandia Baru. Namun, kerap muncul permasalahan akibat aturan perdagangan yang berbeda dari setiap Free Trade Agreement (FTA). Perbedaan aturan tersebut akhirnya membuat pelaku usaha kesulitan dalam memanfaatkan FTA, misalnya keringanan bea masuk(BM) yang telah disepakati dalam FTA. RCEP dirumuskan dengan maksud untuk menyederhanakan aturan-aturan yang berbeda tersebut (Kemenperin, 2018).

Pembentukan RCEP diyakini akan menjadi pasar perdagangan bebas terbesar didunia. RCEP ditargetkan mulai diimplementasikan pada tahun 2020. Kerja sama ini berupaya menghapuskan atau menurunkan hambatan perdagangan. Di satu sisi, RCEP merupakan peluang untuk meningkatkan akses pasar produk pangan. Pangsa pasar RCEP merupakan pasar yang besar mencapai 3,2 miliar jiwa (45 persendari penduduk dunia). Namun pada saat yang bersamaan, Indonesia dihadapkan dengan tantangan dan ancaman yang nyata. Dibandingkan dengan negara-negara anggota RCEP, indeks daya saing Indonesia masih berada di bawah beberapa negara anggota yang lain, khususnya dibandingkan dengan enam negara mitra dan beberapa negara ASEAN.

Berdasarkan UU No.18 Tahun 2012 tentang Pangan, pemenuhan konsumsi pangan harus mengutamakan produksi dalam negeri dengan memanfaatkan sumber daya dan kearifan lokal secara optimal. Hal demikian juga di atur dalam
UU No.41 Tahun 2009 tentang Perlindungan Lahan Pertanian Pangan berkelanjutan bahwa tujuan yang harus dicapai sektor pertanian di Indonesia adalah melindungi dan menjamin kawasan dan lahan pertanian pangan secara berkelanjutan, mewujudkan kemandirian, ketahanan, dan kedaulatan pangan untuk masa depan Indonesia.

Kemandirian dapat dicapai apabila Indonesia menjadi negara yang memiliki serta mampu berdaya saing. Undang-Undang nomor 17 tahun 2007 tentang Rencana Pembangunan Jangka Panjang Nasional (RPJPN) menyebutkan bahwa untuk mencapai negara yang berdaya saing, komponen utama arah pembangunan yang harus dicapai adalah adanya penguatan perekonomian domestik dengan orientasi dan berdaya saing global di mana pembangunan perdagangan berperan penting dalam mewujudkan arah tersebut.

Oleh karena itu, dalam menghadapi perundingan kerja sama RCEP, Indonesia harus mempersiapkan diri sebaik mungkin untuk menjamin agar forum kerja sama RCEP memberikan dampak positif bagi sektor pangan Indonesia. Berdasarkan pemikiran-pemikiran tersebut, maka tulisan ini memiliki tujuan: (i) mengetahui daya saing produk pangan Indonesia di negara anggota RCEP; (ii) mengetahui daya saing produk pangan negara mitra RCEP di Indonesia; (iii) mengetahui posisi produk sektor pangan Indonesia yang dapat dimanfaatkan dalam rangka perdagangaan bebas RCEP; dan (iv) mengetahui posisi produk sektor pangan Indonesia yang perlu dilindungi dalam rangka perdagangan bebas RCEP.

\section{METODOLOGI}

\subsection{Jenis dan Metode Pengumpulan Data}

Penelitian ini adalah penelitian desk study menggunakan data sekunder, di mana/dengan data yang dipilih adalah data perdagangan Indonesia dengan negara mitra RCEP. Data penelitian diperoleh dari database UN Comtrade dan Sekretariat ASEAN. Data perdagangan yang dianalisis adalah data tahun 2014 dan 2018. Hal ini dilandasi bahwa pada periode waktu tersebut tidak terjadi krisis global yang menyebabkan gangguan pada pola permintaan barang ekspor dan tahun 2018 adalah data 
terkini yang tersedia.

Produk yang dianalisis adalah semua produk sektor pangan, termasuk komoditas utama seperti beras, gula, tepung, daging sapi, daging ayam, cabai,, bawang, dan minyak goreng. Jumlah digit Harmonized System (HS) produk menyesuaikan dengan data perdagangan dan tarif yang diterapkan oleh negara mitra RCEP. Data tarif diperoleh dari Sekretariat ASEAN sesuai perjanjian perdagangan FTA yang sudah ada.

\subsection{Metode Analisis Data}

Metode analisis yang dgunakan untuk mengetahui daya saing produk pangan adalah metode Constant Market Share Analysis (CMSA). Metode ini pertama kali diperkenalkan oleh Tyszynski dalam penelitiannya tentang analisis perubahan pada perdagangan komoditas manufaktur pada tahun 1899-1950 (Tatarer, 2004) Perubahan pangsa pasar negara tersebut disebabkan oleh dua hal. Pertama berkaitan dengan perubahan kepentingan relatif dari kelompok komoditas dan yang kedua adalah perubahan pangsa kelompok komoditas individu pada suatu negara.

Metode yang digunakan Tyszynski dikembangkan oleh Leamer dan Stern (1970). Metode CMS Leamer dan Stern mempunyai tiga asumsi yang digunakan yaitu efek komposisi komoditas, efek distribusi pasar, dan efek daya saing.

Perhitungan nilai daya saing pada penelitian ini menggunakan asumsi efek daya saing. Efek daya saing (Competitiveness effect) adalah kemampuan suatu negara untuk meningkatkan pangsa ekspor mereka yang disebabkan oleh perubahan pangsa ekspor negara tersebut untuk produk tertentu di negara tujuan (pangsa ekspor produk $\mathrm{i}$ dari negara $\mathrm{j}$ ke negara k). Peningkatan ini tidak disebabkan oleh perubahan struktural pada ekspor negara j. Efek daya saing merupakan komponen yang mencakup semua aspek pertumbuhan ekspor. Rumus perhitungannya adalah sebagai berikut:

$$
\sum_{k} \sum_{i}\left(\frac{X_{i j k}^{t}}{X_{i . k}^{t}}-\frac{X_{i j k}^{0}}{X_{i . k}^{0}}\right) * \frac{X_{i . k}^{0}}{X_{\ldots}^{0}}
$$

Keterangan:

$0=$ Periode awal dalam analisis

$\mathrm{t}=$ Periode akhir dalam analisis

$\mathrm{Xijk}=$ Ekspor produk $\mathrm{i}$ dari negara $\mathrm{j} \mathrm{ke}$ negara $\mathrm{k}$

Xi.k = Total ekspor dunia untuk produk $\mathrm{i}$ ke negara $\mathrm{k}$

$\mathrm{X}=$ Total ekspor produk pangan dunia ke negara $\mathrm{k}$

Nilai positif CMS menunjukkan produk negara j secara relatif kompetitif di pasar negara k. Oleh karena itu, semakin besar nilai CMS, semakin kompetitif produk tersebut di pasar negara k.

Posisi sektor pangan Indonesia dalam memanfaatkan kerja sama RCEP dapat dianalisis dengan membandingkan nilai CMS yang sudah dianalisis dengan hambatan tarif yang masih diterapkan oleh negara mitra RCEP. Nilai positif CMS menunjukkan produk pangan Indonesia secara relatif kompetitif di pasar negara RCEP. Oleh karena itu, semakin besar nilai CMS, semakin kompetitif produk tersebut di pasar negara mitra RCEP.

Produk pangan Indonesia yang memiliki

Tabel 1. Kategori Produk Sektor Pangan Berdasarkan Analisis Tarif

\begin{tabular}{cll}
\hline Kategori & \multicolumn{1}{c}{ Analisis Tarif } & \multicolumn{1}{c}{ Posisi Sektor Pertanian } \\
\hline Kategori A & $\begin{array}{l}\text { Semua produk yang tarifnya sudah } \\
\text { dihapuskan di semua FTA yang sudah } \\
\text { ada }\end{array}$ & $\begin{array}{l}\text { Boleh ditawarkan untuk Penurunan } \\
\text { Tarif }\end{array}$ \\
Kategori B & $\begin{array}{l}\text { Semua produk yang sensitif/masih } \\
\text { memberlakukan perlindungan tarif di } \\
\text { semua FTA yang sudah ada }\end{array}$ & Wajib dilindungi \\
Kategori C & $\begin{array}{l}\text { Produk yang masih memberlakukan } \\
\text { perlindungan tarif di salah satu/lebih } \\
\text { FTA yang sudah ada }\end{array}$ & Perlu analisis lebih lanjut dengan \\
& & Nilai CMS Negara Mitra RCEP \\
\hline
\end{tabular}


nilai daya saing yang tinggi tetapi masih dikenakan hambatan tarif di pasar negara RCEP dikategorikan sebagai produk sektor pangan prioritas untuk dimanfaatkan dalam rangka kerja sama perdagangan RCEP. Produk tersebut perlu ditingkatkan akses pasarnya ke negara mitra RCEP dengan meminta penghapusan atau penurunan tarif impor di negara mitra RCEP. Sedangkan posisi sektor pangan Indonesia yang perlu dilindungi dalam rangka kerja sama RCEP dapat dikategorikan seperti pada Tabel 1. Kategori produk yang perlu dilindungi adalah produk pangan yang masih menerapkan tarif di semua FTA dengan negara mitra RCEP.

\section{HASIL DAN PEMBAHASAN}

\subsection{Daya Saing Produk Sektor Pangan Indonesia di Negara RCEP}

Daya saing produk sektor pangan Indonesia di negara mitra RCEP diketahui dengan menggunakan metode Analisis Constant Market Share (CMS). Berdasarkan hasil analisis pada Tabel 2, produk pangan Indonesia yang memiliki daya saing atau memiliki nilai CMS positif paling banyak adalah di pasar Australia dengan jumlah 41 produk. Hal ini menunjukkan bahwa ada 41 produk pangan Indonesia yang memiliki daya saing secara relatif di banding negara lain di

Tabel 2. Hasil Analisis Daya Saing Produk Pangan Indonesia dengan Nilai CMS Tertinggi di Pasar Negara Mitra RCEP.

\begin{tabular}{|c|c|c|c|}
\hline Negara & $\begin{array}{c}\text { Jumlah Produk } \\
\text { yang bernilai CMS } \\
\text { Positif }\end{array}$ & Produk Indonesia yang Memiliki Nilai CMS Tertinggi & Nilai CMS \\
\hline \multirow[t]{5}{*}{ Australia } & 41 & Pasta & 0,00185 \\
\hline & & Roti & 0,00057 \\
\hline & & Biskuit & 0,00050 \\
\hline & & Kacang dan bijian lain yang diawetkan & 0,00036 \\
\hline & & Makanan olahan dari produk sereal & 0,00033 \\
\hline \multirow[t]{5}{*}{ China } & 26 & Waffle dan wafer & 0,00022 \\
\hline & & Fraksi minyak nabati lainnya & 0,00003 \\
\hline & & Mie Instant & 0,00003 \\
\hline & & Margarin lainnya, fraksi dari minyak nabati/hewani & 0,00002 \\
\hline & & Fraksi minyak sawit lainnya & 0,00001 \\
\hline \multirow[t]{5}{*}{ India } & 28 & Tetes tebu & 0,00057 \\
\hline & & Biskuit manis & 0,00009 \\
\hline & & Minyak dan lemak nabati dan fraksinya & 0,00008 \\
\hline & & Wafel dan Wafer & 0,00007 \\
\hline & & Roti & 0,00005 \\
\hline \multirow[t]{5}{*}{ Jepang } & 38 & Wafel komuni dan roti & 0,00018 \\
\hline & & Fraksi minyak nabati yang dihidrogenasi & 0,00012 \\
\hline & & Ubi jalar, segar/kering, beku & 0,00003 \\
\hline & & Tetes tebu & 0,00002 \\
\hline & & Buah dan bagian tanaman yang diolah mengandung gula & 0,00001 \\
\hline \multirow[t]{5}{*}{ Korea } & 28 & Minyak kelapa dan fraksinya & 0,00047 \\
\hline & & Biskuit manis & 0,00016 \\
\hline & & Buah dan bagian tanaman yang diolah mengandung gula & 0,00015 \\
\hline & & $\begin{array}{l}\text { Campuran adonan tepung, menir, tepung, pati atau } \\
\text { ekstrak malt, }\end{array}$ & 0,00008 \\
\hline & & Sekam, dedak, residu lainnya dari gandum & 0,00008 \\
\hline Selandia & 36 & Pasta & 0,00045 \\
\hline \multirow{4}{*}{ Baru } & & Biskuit manis & 0,00041 \\
\hline & & Makanan Olahan dari sereal & 0,00037 \\
\hline & & Campuran minyak nabati atau hewani & 0,00031 \\
\hline & & Gula lainnya; termasuk gula invert serta campuran sirup & 0,00026 \\
\hline
\end{tabular}

Sumber : UN Comtrade, 2019 (diolah) 
Tabel 3. Hasil Analisis Daya Saing Produk Pangan Negara Mitra RCEP dengan Nilai CMS Tertinggi di Pasar Indonesia

\begin{tabular}{|c|c|c|c|}
\hline Negara & $\begin{array}{l}\text { Jumlah Produk yang } \\
\text { bernilai CMS Positif }\end{array}$ & Produk Negara Mitra yang Memiliki Nilai CMS Tertinggi & Nilai CMS \\
\hline \multirow[t]{5}{*}{ Australia } & \multirow[t]{5}{*}{60} & Jagung (tidak termasuk benih) & 0,00061 \\
\hline & & Kacang yang dikeringkan & 0,00046 \\
\hline & & Potongan daging lembu bertulang beku & 0,00038 \\
\hline & & Daging lembu tanpa tulang, segar atau dingin & 0,00017 \\
\hline & & Tepung Gandum & 0,00009 \\
\hline \multirow[t]{5}{*}{ China } & \multirow[t]{5}{*}{79} & Residu dari pembuatan pati lainnya & 0,00520 \\
\hline & & Fruktosa sirup, mengandung fruktosa $>50 \%$ & 0,00255 \\
\hline & & Jagung - maize & 0,00196 \\
\hline & & Glukosa & 0,00104 \\
\hline & & Kembang gula lainnya & 0,00073 \\
\hline \multirow[t]{5}{*}{ India } & \multirow[t]{5}{*}{39} & Daging sapi tanpa tulang, beku & 0,01694 \\
\hline & & Beras semi/whooly milling & 0,00219 \\
\hline & & Beras pecah & 0,00126 \\
\hline & & Benih jagung & 0,00027 \\
\hline & & Lemak mentega anhidrat & 0,00024 \\
\hline \multirow[t]{5}{*}{ Jepang } & \multirow[t]{5}{*}{48} & Olahan campuran dari minyak nabati/hewani & 0,00036 \\
\hline & & Produk roti & 0,00016 \\
\hline & & Pasta lainnya & 0,00005 \\
\hline & & Kembang gula lainnya & 0,00005 \\
\hline & & Maltosa kimiawi murni & 0,00003 \\
\hline \multirow[t]{5}{*}{ Korea } & \multirow[t]{5}{*}{34} & Pasta dan mie instan lainnya & 0,00020 \\
\hline & & Produk roti & 0,00005 \\
\hline & & Biskuit manis & 0,00003 \\
\hline & & Fraksi minyak jagung & 0,00002 \\
\hline & & Makanan olahan lain dari sereal & 0,00002 \\
\hline & \multirow[t]{5}{*}{11} & Olahan campuran dari minyak nabati/hewani & 0,00025 \\
\hline \multirow{4}{*}{ Baru } & & Olahan makanan ekstrak malt lainnya mengandung susu & 0,00005 \\
\hline & & Kacang polong kering & 0,00004 \\
\hline & & Kacang kedelai & 0,00002 \\
\hline & & Kacang polong beku & 0,00001 \\
\hline
\end{tabular}

Sumber : UN Comtrade, 2019 (diolah)

pasar Australia. Sedangkan jumlah paling sedikit di pasar India dan Korea yang berjumlah 28 produk.

Jumlah produk yang memiliki nilai CMS positif di tiap negara mitra berbeda. Hal ini kemungkinan disebabkan adanya perbedaan karakteristik kebutuhan dan kemampuan negara mitra RCEP dalam memenuhi permintaan dalam negerinya. Akibatnya, produk yang diimpor dari Indonesia juga berbeda.

Produk pangan Indonesia yang memiliki daya saing di pasar Australia sebagian besar adalah produk pangan olahan seperti biskuit, roti, pasta, dan makanan olahan dari sereal. Produk tersebut memang disukai oleh penduduk Australia dan menjadi makanan pokok seharihari. Australia bahkan mengimpor produk pasta dari Indonesia sejumlah 19,4 juta USD atau 33 persen dari total impornya pada tahun 2018 . Produk pangan Indonesia yang memiliki daya saing di pasar Australia semuanya mengalami peningkatan ekspor. Contohnya yang mengalami peningkatan cukup tinggi adalah roti. Nilai ekspor roti Indonesia ke Australia mencapai 8,7 juta USD pada tahun 2018. Nilai tersebut meningkat 3,7 juta USD dibandingkan tahun 2014 yang nilai ekspornya 5 juta USD.

Produk pangan Indonesia yang memiliki nilai daya saing tertinggi di pasar China adalah waffle dan wafer. Nilai ekspor waffle dan wafer Indonesia ke China mencapai 106 juta USD pada tahun 2018. Waffle dan wafer Indonesia memiliki pangsa 70 persen dari total impor produk tersebut di China. Produk pangan Indonesia yang memiliki daya saing di pasar China semuanya mengalami peningkatan ekspor. Produk pangan berdaya saing Indonesia yang 
memiliki nilai ekspor tinggi adalah margarin. Nilai ekspor margarin Indonesia ke China mencapai 301 juta USD pada tahun 2018. Total impor margarin China sejumlah 309 juta USD, sehingga margarin Indonesia memiliki pangsa sejumlah 97 persen di pasar China.

Produk pangan Indonesia yang memiliki daya saing di pasar India sebagian besar adalah produk pangan olahan seperti roti, waffle, wafer, biskuit, dan fraksi minyak nabati. Produk pangan Indonesia yang memiliki daya saing di pasar India semuanya mengalami peningkatan ekspor. India merupakan pasar potensial dengan jumlah penduduk mencapai 1,3 miliar jiwa. Penduduk India yang sebagian besar umat Hindu lebih hati-hati dalam mengkonsumsi minyak hewani, sehingga lebih memilih untuk mengkonsumsi minyak nabati. Hal ini merupakan peluang untuk meningkatkan ekspor fraksi minyak nabati atau minyak goreng ke India. Indonesia selama ini lebih banyak ekspor minyak sawit mentah.

Produk pangan Indonesia yang memiliki daya saing di pasar Jepang berupa produk pangan olahan seperti roti, wafel, tetes tebu, dan fraksi minyak nabati. Nilai ekspor waffle dan roti Indonesia ke Jepang mencapai 9,3 juta USD pada tahun 2018. Produk pangan lainnya yang memiliki daya saing dan nilai ekspor tinggi adalah ubi jalar. Nilai ekspor ubi jalar mencapai 4,5 juta USD pada tahun 2018. Nilai ekspor tersebut meningkat 1,3 juta USD dibanding tahun 2014.

Produk pangan Indonesia yang memiliki daya saing di pasar Jepang ada yang mengalami penurunan ekspor, produk tersebut adalah campuran buah dan kacang-kacangan yang diawetkan. Tahun 2018 nilai ekspor produk tersebut berjumlah 712 ribu USD atau menurun sejumlah 111 ribu USD dibandingkan tahun 2014 yang nilai ekspornya mencapai 823 ribu USD. Namun secara keseluruhan nilai impor Jepang untuk produk buah dan kacang yang diawetkan menurun lebih tinggi, yaitu menurun sejumlah 4,7 juta USD.

Produk pangan Indonesia yang memiliki daya saing di pasar Korea sebagian besar berupa produk pangan olahan. Produk tersebut mengalami peningkatan ekspor ke Korea pada tahun 2018. Minyak kelapa merupakan produk yang paling tinggi nilai ekspor dan kenaikan ekspornya pada tahun 2018. Nilai ekspor minyak kelapa mencapai 72,9 juta USD pada tahun 2018, meningkat sejumlah 4,6 juta USD dibandingkan tahun 2014.

Produk pangan Indonesia yang memiliki daya saing di pasar Korea ada yang mengalami penurunan ekspor, produk tersebut adalah sekam atau dedak berupa pelet dari gandum. Tahun 2018 nilai ekspor produk tersebut berjumlah 13,1 juta USD atau menurun sejumlah 26,8 juta USD dibandingkan nilai ekspor tahun 2014 yang mencapai 39,9 juta USD. Namun secara keseluruhan nilai impor Korea untuk produk tersebut menurun lebih besar, yaitu menurun sejumlah 34,9 juta USD.

Produk pangan Indonesia yang memiliki daya saing di pasar Selandia Baru sebagian besar adalah produk pangan olahan seperti biskuit, pasta, minyak nabati, dan makanan olahan dari sereal. Produk tersebut mengalami peningkatan ekspor pada tahun 2018. Produk pangan Indonesia yang memiliki daya saing di pasar Selandia Baru yang mengalami penurunan ekspor adalah margarin. Tahun 2018 nilai ekspor margarin berjumlah 323 ribu USD atau menurun sejumlah 300 ribu USD dibandingkan nilai ekspor tahun 2014 yang mencapai 623 ribu USD. Namun secara keseluruhan nilai impor Selandia Baru untuk produk margarin menurun lebih besar, yaitu menurun sejumlah 434 ribu USD.

\subsection{Daya Saing Produk Sektor Pangan Negara Mitra RCEP di Indonesia}

Hasil analisis daya saing produk pangan negara mitra RCEP di pasar Indonesia dapat di lihat pada Tabel 3. Berdasarkan hasil analisis CMS terhadap produk mitra RCEP, produk pangan Australia yang memiliki daya saing di pasar Indonesia atau memiliki nilai CMS positif berjumlah 60 produk. Produk pangan Australia yang memiliki daya saing tinggi di pasar Indonesia diantaranya adalah jagung, daging, kacang, dan tepung gandum. Produk gandum dan daging, selain memiliki daya saing tinggi di pasar Indonesia, produk tersebut merupakan produk pangan yang paling banyak di ekspor Australia ke Indonesia. Australia juga memiliki nilai ekspor yang cukup tinggi untuk produk 
jeroan sapi yang mencapai 40,7 juta USD pada tahun 2018

Jumlah produk pangan Australia yang memiliki nilai CMS positif lebih banyak dibanding produk pangan Indonesia yang memiliki nilai CMS positif di pasar Australia, yaitu 60 berbanding 41. Hal ini menunjukkan bahwa Australia punya lebih banyak pilihan produk pertanian yang dapat dinegoisasikan untuk liberalisasi perdagangan forum RCEP.

Produk pangan China yang memiliki daya saing di pasar Indonesia atau memiliki nilai CMS positif berjumlah 79 produk. Produk pangan China yang memiliki daya saing tinggi di pasar Indonesia di antaranya adalah jagung, fruktosa, biskuit, gandum, bawang putih, dan kecap manis. Selain memiliki daya saing paling tinggi, produk jagung dan bawang putih merupakan produk pangan yang paling banyak di ekspor China ke Indonesia. Ekspor bawang putih China ke Indonesia mencapai 493 juta USD pada tahun 2018. Bawang putih dari China mencapai 90 persen lebih, sehingga Indonesia memiliki ketergantungan yang tinggi terhadap bawang putih dari China. Jumlah produk pangan China yang memiliki nilai CMS positif lebih banyak dibanding produk pangan Indonesia yang memiliki nilai CMS positif di pasar China, yaitu 79 berbanding 26 produk.

Produk pangan India yang memiliki daya saing di pasar Indonesia atau memiliki nilai CMS positif berjumlah 39 produk. Produk pangan India yang memiliki daya saing tinggi di pasar Indonesia diantaranya adalah daging sapi, beras pecah, lemak mentega, dan benih jagung. Selain memiliki daya saing paling tinggi, daging sapi merupakan produk pangan yang paling banyak di ekspor India ke Indonesia. Ekspor daging sapi beku tanpa tulang India ke Indonesia mencapai 283,6 juta USD pada tahun 2018. Jumlah produk pangan India yang memiliki nilai CMS positif lebih banyak dibanding produk pangan Indonesia yang memiliki nilai CMS positif di pasar India, yaitu 39 berbanding 28 .

Produk pangan Jepang yang memiliki daya saing di pasar Indonesia atau memiliki nilai CMS positif berjumlah 48 produk. Produk pangan Jepang yang memiliki daya saing tinggi di pasar Indonesia diantaranya adalah roti, pasta, olahan campuran minyak nabati, kembang gula, maltosa, daging lembu, dan tepung. Jumlah produk pangan Jepang yang memiliki nilai CMS positif lebih banyak dibanding produk pangan Indonesia yang memiliki nilai CMS positif di pasar Jepang, yaitu 48 berbanding 38 .

Produk pangan Korea yang memiliki daya saing di pasar Indonesia atau memiliki nilai CMS positif berjumlah 34 produk. Produk pangan Korea yang memiliki daya saing tinggi di pasar Indonesia diantaranya adalah pasta, mi instan, roti, biskuit, minyak jagung, dan makanan olahan dari produk serealia. Jumlah produk pangan Korea yang memiliki nilai CMS positif lebih banyak dibanding produk pangan Indonesia yang memiliki nilai CMS positif di pasar Korea, yaitu 34 berbanding 28 .

Produk pangan Selandia Baru yang memiliki daya saing di pasar Indonesia atau memiliki nilai CMS positif berjumlah 11 produk. Produk pangan Selandia Baru yang memiliki daya saing tinggi di pasar Indonesia diantaranya adalah olahan campuran minyak nabati, kacang polong, kacang kedelai, dan makanan olahan. Jumlah produk pangan Selandia Baru yang memiliki nilai CMS positif lebih sedikit dibanding produk pangan Indonesia yang memiliki nilai CMS positif di pasar Selandia Baru, yaitu 11 berbanding 36 .

Berdasarkan Gambar 2, produk pangan Indonesia yang memiliki daya saing positif dan lebih banyak jumlahnya dibanding negara mitra RCEP adalah hanya terhadap Selandia Baru. Tetapi apabila dibandingkan lima negara lainnya, produk berdaya saing Indonesia jumlahnya lebih sedikit. Terlebih apabila dibandingkan dengan produk pangan dari Australia dan China, perbedaanya cukup jauh.

Secara umum produk pangan negara mitra RCEP yang memiliki daya saing di pasar Indonesia terdiri dari produk pangan olahan dan produk pangan segar yang belum di olah lebih lanjut. Contoh produk pangan olahan antara lain pasta, mi instan, fruk tosa sirup, kembang gula, dan biskuit. Contoh produk pangan yang belum di olah lebih lanjut antara lain daging sapi, kacang kedelai, kacang polong, jagung, dan beras. 


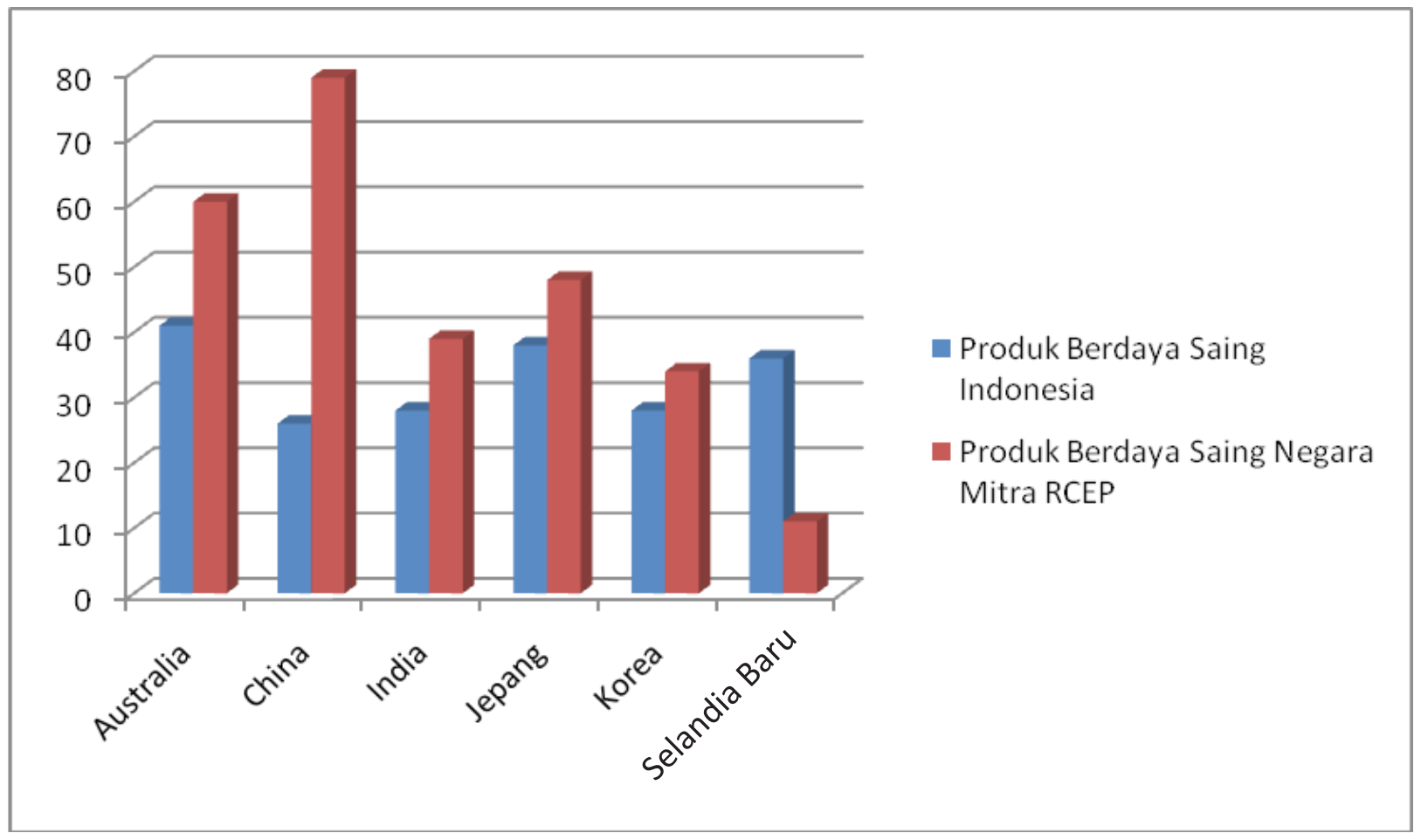

Gambar 2 Perbandingan Jumlah Produk Pangan Indonesia dan Negara Mitra RCEP yang Memiliki Nilai Daya Saing Positif

Sumber : UN Comtrade, 2019 (diolah)

\subsection{Posisi Sektor Pangan Indonesia dalam Memanfaatkan RCEP}

Kerja sama RCEP bertujuan untuk liberalisasi perdagangan di antara anggotanya, yaitu penghapusan atau penurunan tarif impor di negara anggota RCEP. Tarif impor merupakan salah satu penghambat perdagangan, sehingga apabila tarif impor negara mitra RCEP dapat dihapuskan atau diturunkan dalam kerangka kerja sama RCEP, maka diharapkan bermanfaat untuk meningkatkan akses pasar produk pangan Indonesia.

Posisi sektor pangan Indonesia dalam memanfaatkan perdagangan bebas RCEP dianalisis dengan membandingkan hambatan tarif yang masih diterapkan oleh negara mitra RCEP dengan nilai CMS produk pangan Indonesia. Nilai positif CMS menunjukkan produk Indonesia secara relatif kompetitif di pasar negara RCEP. Oleh karena itu, semakin besar nilai CMS, semakin kompetitif produk tersebut di pasar negara RCEP. Produk pangan Indonesia yang berdaya saing dan masih dikenakan tarif di pasar negara RCEP masuk kategori prioritas untuk dimanfaatkan dalam rangka perdagangan bebas RCEP. Produk tersebut posisinya adalah prioritas untuk diperjuangkan dengan meminta penghapusan atau penurunan tarif kepada negara mitra selama perundingan RCEP masih berlangsung.

Berdasarkan hasil analisis CMS produk pangan Indonesia di pasar Australia dan Selandia Baru pada Tabel 4, maka diperoleh produk pangan Indonesia yang berdaya saing tinggi di Australia berjumlah 41 produk dan di Selandia Baru berjumlah 36 produk. Tetapi semua produk tersebut sudah tidak ada hambatan tarifnya di Australia dan Selandia Baru. Tarif impor yang sudah dihapuskan mungkin mengindikasikan bahwa Australia dan Selandia Baru memiliki fondasi produk pangan dalam negeri yang kuat sehingga mampu menerapkan tarif nol persen terhadap produk pertanian Indonesia. Interpretasi lain akan rendahnya tarif impor Australia dan Selandia Baru adalah mungkin negara tersebut lebih banyak memberlakukan hambatan perdagangan bukan tarif.

Oleh karena itu, Indonesia tidak perlu negoisasi penurunan tarif lagi ke Australia dan Selandia Baru. Hambatan tarif untuk akses 
Tabel 4. Jumlah Produk Pangan Indonesia dengan Nilai Daya Saing Positif dan Terdapat Hambatan Tarif di Negara Mitra RCEP

\begin{tabular}{|c|c|c|c|c|}
\hline Negara & $\begin{array}{l}\text { Jumlah } \\
\text { Produk } \\
\text { Berdaya } \\
\text { Saing }\end{array}$ & $\begin{array}{c}\text { Jumlah Produk } \\
\text { Berdaya Saing } \\
\text { tetapi ada } \\
\text { Hambatan Tarif }\end{array}$ & $\begin{array}{l}\text { Hambatan } \\
\text { Tarif }\end{array}$ & $\begin{array}{c}\text { Contoh Produk dan Hambatan } \\
\text { Tarifnya }\end{array}$ \\
\hline Australia & 41 & 0 & $0 \%$ & $\begin{array}{l}\text { Semua produk sudah dibebaskan } \\
\text { hambatan tarifnya }\end{array}$ \\
\hline China & 26 & 23 & $5 \%$ & $\begin{array}{l}\text { Waffle, wafer, serbuk gula, mi instant, } \\
\text { margarin, saus, kecap, pati kentang, } \\
\text { Fraksi minyak nabati lainnya }\end{array}$ \\
\hline India & 28 & 5 & $30 \%-80 \%$ & $\begin{array}{l}\text { Fraksi minyak dan lemak nabati }(80 \%) \text {, } \\
\text { Buah/bagian tanaman dapat dimakan } \\
\text { diawetkan (30\%), kacang dan biji; } \\
\text { campuran buah kacang-kacangan } \\
\text { diawetkan }(30 \%) \text {, Fraksi minyak nabati } \\
\text { dihidrogenasi }(80 \%)\end{array}$ \\
\hline Jepang & 38 & 16 & $3,8 \%-28 \%$ & $\begin{array}{l}\text { Ubi jalar }(3,8 \%) \text {, tepung-tepung sagu } \\
(6,7 \%) \text {, daging unggas }(5 \%) \text {, kacang } \\
\text { tanah }(23,8 \%) \text {, kembang gula }(25 \%) \text {, } \\
\text { ekstrak malt }(28 \%)\end{array}$ \\
\hline Korea & 28 & 2 & $5 \% \& 40 \%$ & $\begin{array}{l}\text { Gula tebu atau bit dan sukrosa murni } \\
\text { secara kimiawi }(40 \%) \text {, Tepung, tepung } \\
\text { kasar dan bubuk }(5 \%)\end{array}$ \\
\hline $\begin{array}{l}\text { Selandia } \\
\text { Baru }\end{array}$ & 36 & 0 & $0 \%$ & $\begin{array}{l}\text { Semua produk sudah dibebaskan } \\
\text { hambatan tarifnya }\end{array}$ \\
\hline
\end{tabular}

Sumber : UN Comtrade dan Sekretariat ASEAN, 2019 (diolah)

pasar ke Australia dan Selandia Baru sudah nol persen, sehingga peningkatan akses pasar ke Australia dan Selandia Baru dapat dilakukan dengan penghapusan hambatan non tarif terhadap produk pangan Indonesia oleh Australia dan Selandia Baru. Contoh hambatan selain tarif impor yang biasa dilakukan seperti penerapan standar mutu dan karantina yang tinggi, praktik damping, serta persyaratan packaging dan labelling.

Hasil analisis CMS produk pangan Indonesia di pasar China menunjukkan bahwa dari 26 produk pangan Indonesia yang memiliki daya saing, terdapat 23 produk pangan Indonesia yang masih mendapat hambatan tarif. Produk tersebut diantaranya adalah mi instan, wafel, wafer, saus, kecap, dan makanan olahan dari buah atau kacang-kacangan. Produk tersebut masih ada hambatan tarif sebesar 5 persen oleh China. Dengan demikian untuk meningkatkan akses pasar Indonesia ke China, maka untuk produk tersebut dapat diminta penurunan tarifnya selama perundingan RCEP masih berlangsung.
Tumbuh pesatnya ekonomi China dalam dua dekade terakhir telah membawa perubahan posisi geopolitik kepada negara-negara di Asia Pasifik. ASEAN yang berada pada wilayah tersebut juga turut merasakan dampak pengaruh China baik dalam bidang ekonomi, politik, dan keamanan. Perekonomian China yang telah bangkit dapat menjadi peluang dan ancaman bagi negara ASEAN seperti Indonesia. Namun demikian, kebangkitan China juga dapat menjadi balancing power bagi hegemoni Amerika Serikat di ASEAN. Penduduk China yang besar merupakan target pasar yang menjanjikan.

Hasil analisis CMS produk pangan Indonesia di pasar India menunjukkan bahwa dari 28 produk pangan Indonesia yang memiliki daya saing, terdapat 5 produk yang masih mendapat hambatan tarif. Produk tersebut diantaranya adalah produk olahan buah, kacang, dan biji-bijian yang diawetkan serta fraksi minyak nabati. Hambatan tarif untuk produk pangan Indonesia di pasar India cukup tinggi, yaitu sebesar 30 persen sampai 80 persen. Oleh karena itu, untuk meningkatkan akses pasar Indonesia ke India, produk-produk 
tersebut diprioritaskan penurunan tarifnya selama perundingan RCEP masih berlangsung.

Jumlah penduduk yang besar menjadikan India sangat berpotensi menjadi emerging market yang sangat besar bagi produk pangan Indonesia. Penguasaan India pada bidang teknologi informasi juga dapat dimanfaatkan melalui proses transfer teknologi. Kerja sama perdagangan RCEP merupakan peluang strategis dalam peningkatan hubungan Indonesia-India, terutama dalam memanfaatkan keunggulan yang dimiliki India dan penurunan hambatan perdagangan. Selain itu, kesamaan latar belakang dan ciri-ciri yang dimiliki antara Indonesia dan India juga dapat dimanfaatkan sebagai potensi dasar dalam peningkatan hubungan dan kerja sama perdagangan antara Indonesia dan India.

Hasil analisis CMS produk pangan Indonesia di pasar Jepang menunjukkan bahwa dari 38 produk pangan Indonesia yang memiliki daya saing, terdapat 16 produk yang masih mendapat hambatan tarif. Hambatan tarif yang masih diberlakukan oleh Jepang mulai dari 3,8 persen sampai dengan 28 persen. Produk ubi jalar (HS. 071420100) memiliki hambatan tarif terkecil yaitu 3,8 persen. Produk yang memiliki hambatan tarif tertinggi sebesar 28 persen adalah ekstrakt malt dan makanan olahan dari tepung. Oleh karena itu, untuk meningkatkan akses pasar Indonesia ke Jepang, produkproduk tersebut diprioritaskan dapat diturunkan tarifnya.

Hasil analisis CMS produk pangan Indonesia di pasar Korea menunjukkan bahwa dari 28 produk pangan Indonesia yang memiliki daya saing, hanya ada 2 produk yang masih mendapat hambatan tarif. Hambatan tarif yang masih diberlakukan oleh korea adalah 5 persen untuk produk tepung dan 40 persen untuk produk gula tebu atau bit dan sukrosa murni secara kimiawi.

Korea Selatan selama ini menggunakan strategi outward looking industry telah berhasil menjadi salah satu negara industri yang kuat di Asia dan dunia. Di Asia, Korea Selatan bersaing ketat dengan Jepang dalam menguasai pasar industri Asia, terutama di bidang otomotif dan teknologi. Menyadari kelemahan negaranya yang kurang memiliki kekayaan sumber daya alam dan pasar domestik yang terbatas, Korea Selatan berusaha memperluas pasar perdagangannya dengan melakukan kerja sama dengan negara-negara lain, termasuk negara ASEAN dan Indonesia. Oleh karena itu, walaupun sebagian besar tarif impor produk pangan berdaya saing Indonesia sudah dihapuskan, Indonesia masih perlu mengajukan penurunan tarif untuk produk tersebut, seperti tepung dan gula tebu atau bit.

Berdasarkan Tabel 4, negara yang paling banyak memiliki hambatan tarif terhadap produk pangan Indonesia yang memiliki daya saing positif adalah China. Tetapi besaran tarif yang diberlakukan China tidak terlalu besar yaitu 5 persen. Negara yang masih memberikan hambatan tarif cukup tinggi adalah India dan Jepang. India bahkan menerapkan tarif 80 persen untuk produk fraksi minyak nabati.

China dan India merupakan pasar raksasa di mana jumlah penduduknya adalah yang terbanyak di dunia atau berjumlah total 2,6 miliar jiwa. Sehingga produk pangan berdaya saing Indonesia yang masih ada hambatan tarif di China dan India perlu lebih diprioritaskan untuk ditingkatkan akses pasarnya. Peningkatan akses pasar dalam rangka kerja sama RCEP ini dapat dilakukan dengan negoisasi penurunan atau penghapusan hambatan tarif di negara mitra RCEP.

Berdasarkan hasil analisis CMS dan perbandingan hambatan tarif, maka peningkatan akses pasar Indonesia dalam memanfaatkan kerja sama perdagangan RCEP adalah mengusulkan penghapusan atau penurunan tarif produk pangan Indonesia yang berjumlah 23 produk di China, 5 produk di India, 16 produk di Jepang, dan 2 produk di Korea. Sedangkan peningkatan akses pasar produk pangan Indonesia di pasar Australia dan Selandia Baru adalah dengan usulan pengurangan hambatan non tarif, karena hambatan tarif di dua negara tersebut sudah tidak ada.

\subsection{Posisi Sektor Pangan Indonesia yang Masih Perlu Perlindungan Tarif}

Berdasarkan analisis tarif impor yang diberlakukan oleh Indonesia kepada negara mitra RCEP pada Tabel 5, terdapat 260 produk 
Tabel 5. Kategori dan Posisi Produk Sektor Pertanian Indonesia dalam Menghadapi Liberalisasi RCEP

\begin{tabular}{rlc}
\hline Kategori & \multicolumn{1}{c}{ Posisi } & Jumlah \\
\hline Kategori A & $\begin{array}{l}\text { Semua produk yang tarifnya sudah dihapuskan di semua FTA } \\
\text { yang sudah ada/ boleh ditawarkan }\end{array}$ & 260 produk \\
Kategori B & $\begin{array}{l}\text { Semua produk yang sensitif/ masih memberlakukan } \\
\text { perlindungan tarif di semua FTA yang sudah ada/ wajib di } \\
\text { lindungi }\end{array}$ & 17 Produk \\
Kategori C & $\begin{array}{l}\text { Produk yang masih memberlakukan perlindungan tarif di salah } \\
\text { satu/lebih FTA yang sudah ada }\end{array}$ & 257 Produk \\
\hline
\end{tabular}

Sumber : Sekretariat ASEAN, 2019 (diolah)

pangan yang sudah dibebaskan tarifnya oleh Indonesia di semua perjanjian FTA dengan negara mitra RCEP. Produk pada kategori $A$ ini menunjukkan bahwa negara mitra RCEP dapat memasuki pasar Indonesia untuk produk tersebut dengan tarif impor nol persen. Sehingga apabila negara mitra RCEP meminta penghapusan tarif produk tersebut dalam perundingan RCEP, maka Indonesia dapat memberikannya karena tidak berpengaruh lagi. Hal ini disebabkan Indonesia sudah menghapus tarif produk tersebut menjadi nol di perjanjian FTA yang sudah diimplementasikan.

Produk kategori A yang dibebaskan tarifnya diharapkan menjadi sumber bahan baku atau input untuk dikembangkan menjadi produk yang memiliki nilai tambah. Sedangkan produk lainnya yang diperkirakan akan mengganggu daya saing usaha produk dalam negeri, maka usaha yang dapat dilakukan adalah dengan kebijakan hambatan non tarif. Kebijakan tarif tidak akan berpengaruh karena diperjanjian perdagangan yang sudah berlangsung dengan negara mitra, Indonesia sudah menghapuskan tarif dalam kategori A. Kebijakan non tarif seperti kebijakan standar mutu, kesehatan, dan keamanan dapat dilakukan. Contohnya yang mungkin dapat dilakukan adalah penerapan Sertifikat Halal, Standar Nasional Indonesia (SNI). Namun demikian, kebijakan tersebut harus memerhatikan aturan perdagangan internasional agar tidak bermasalah di masa mendatang.

Pada Tabel 5, Indonesia menerapkan perlindungan kepada 17 produk di semua perjanjian FTA dengan negara mitra RCEP. Hal ini berarti bahwa Indonesia masih menerapkan perlindungan tarif untuk produk tersebut dari semua negara mitra RCEP. Oleh karena itu, produk tersebut wajib dilindungi atau dimasukkan kedalam produk yang sensitif untuk diturunkan tarifnya. Apabila negara mitra RCEP meminta penurunan atau penghapusan produk tersebut, maka Indonesia perlu menolaknya. Produk yang masuk kategori ini adalah beras dan gula. Beras dan gula merupakan produk sensitif dan strategis bagi ketahanan pangan nasional. Beras dan gula merupakan penyedia bahan pokok makanan, bahan baku untuk sektor industri, dan penyerap tenaga kerja penduduk Indonesia. Sehingga beras dan gula masih perlu mendapat perlindungan tarif impor.

Kategori produk sektor pangan lainnya adalah produk yang mendapatkan perlindungan tidak di semua negara mitra RCEP. Misalnya produk daging paha unggas (HS. 0207142000) tarifnya sudah nol persen untuk negara China, tetapi ke negara India, Korea, Australia, Selandia Baru, dan Jepang masih diterapkan tarif sebesar 5 persen sampai 25 persen. Produk yang masuk kategori ini perlu dianalisis lebih lanjut dengan melihat nilai daya saing setiap mitra negara RCEP dengan kebijakan pangan nasional.

Berdasarkan hasil analisis CMS produk pangan Australia di pasar Indonesia pada Tabel 6 , dari 60 produk pangan Australia yang memiliki daya saing terdapat 10 produk pangan Australia yang masih mendapat hambatan tarif di Indonesia. Produk tersebut di antaranya adalah mentega, jagung, daging, jeroan, dan hati sapi. Produk Australia yang memiliki daya saing kemungkinan akan diminta untuk diturunkan atau dihapuskan tarifnya di Indonesia. 
Tabel 6. Jumlah Produk Pangan Mitra yang Memiliki Nilai Daya Saing Positif tetapi Masih ada Hambatan Tarif di Indonesia

\begin{tabular}{|c|c|c|c|c|}
\hline Negara & $\begin{array}{l}\text { Jumlah } \\
\text { Produk } \\
\text { Berdaya } \\
\text { Saing }\end{array}$ & $\begin{array}{l}\text { Jumlah Produk } \\
\text { Berdaya Saing ada } \\
\text { Hambatan Tarif }\end{array}$ & Hambatan Tarif & $\begin{array}{c}\text { Contoh Produk } \\
\text { dan Hambatan Tarifnya }\end{array}$ \\
\hline ustralia & 60 & 10 & $4-5 \%$ & $\begin{array}{l}\text { Jagung, potongan daging lembu } \\
\text { bertulang beku, daging lembu } \\
\text { tanpa tulang, jeroan dan hati } \\
\text { sapi, daging domba (5\%); } \\
\text { mentega, campuran adonan roti } \\
\text { dan tepung }(4 \%)\end{array}$ \\
\hline China & 79 & 1 & Rp450,00/kg & Beras berkulit, padi/gabah \\
\hline India & 39 & 18 & $4,5 \%-10 \%$ & $\begin{array}{l}\text { Daging sapi tanpa tulang, beras } \\
\text { pecah, benih jagung, molases, } \\
\text { bawang putih, tepung gandum, } \\
\text { menir }\end{array}$ \\
\hline Jepang & 48 & 10 & $5 \%-$ MFN & $\begin{array}{l}\text { Gula tebu/bit }(\mathrm{Rp} 790,00 / \mathrm{kg}) \text {, } \\
\text { daging lembu }(5 \%), \text { jagung } \\
(5 \%) \text {, sake }(\operatorname{Rp} 55.000,00 / \mathrm{lt})\end{array}$ \\
\hline Korea & 34 & 1 & Rp55.000,00/ltr & Sake \\
\hline Selandia Baru & 11 & 1 & $5 \%$ & Kacang kedelai \\
\hline
\end{tabular}

Sumber : UN Comtrade dan Sekretariat ASEAN, 2019 (diolah)

Tetapi produk pangan Indonesia sudah dihapuskan semua tarifnya di Australia, sehingga tidak perlu mengajukan penghapusan tarif lagi. Oleh karena itu, apabila Australia mengajukan penurunan atau penghapusan tarif, Indonesia perlu menolaknya. Hal lain yang dapat dilakukan adalah mengajukan penghapusan hambatan non tarif di Australia atau mengajukan kerja sama yang menguntungkan sektor pangan yang nilainya sebanding dengan permintaan penghapusan tarif produk Indonesia.

Hasil analisis CMS produk pangan China di pasar Indonesia menunjukkan bahwa dari 79 produk pangan China yang memiliki daya saing, terdapat 1 produk pangan China yang masih mendapat hambatan tarif di Indonesia. Produk tersebut adalah beras berkulit, padi atau gabah. Produk tersebut masuk dalam kategori sensitif sehingga apabila China meminta penurunan tarif, Indonesia perlu menolaknya. China kemungkinan akan mengajukan produk pangan yang kurang berdaya saing untuk diturunkan atau dihapuskan tarifnya oleh Indonesia. Permintaan ini sangat mungkin diajukan China mengingat ada 23 produk pangan Indonesia yang memiliki daya saing di pasar China masih ada hambatan tarif.
Produk pangan yang paling banyak di impor dari China oleh Indonesia adalah bawang putih. Nilai impor bawang putih mencapai 493 juta USD pada tahun 2018. Namun demikian, bawang putih tarifnya sudah nol persen di Indonesia. Sehingga apabila ingin mengendalikan impor produk tersebut, Indonesia dapat menerapkan kebijkan non tarif. Kebijakan non tarif yang dapat dilakukan seperti penerapan standar kesehatan dan keamanan, penerapan ambang batas pestisida atau bahan pengawet makanan.

Berdasarkan hasil analisis CMS produk pangan India di pasar Indonesia, dari 39 produk pangan India yang memiliki daya saing terdapat 18 produk pangan India yang masih mendapat hambatan tarif di Indonesia. Produk tersebut diantaranya adalah Daging sapi tanpa tulang, beras pecah, benih jagung, molases, bawang putih, tepung gandum, dan menir. Produk tersebut masih ada hambatan tarif sebesar 4,5 persen sampai 10 persen. India dapat mengajukan produk pangannya yang berdaya saing untuk diturunkan atau dihapuskan tarifnya oleh Indonesia. Hal yang menjadi pertimbangan adalah ada 5 produk pangan Indonesia yang memiliki daya saing di pasar India yang masih ada hambatan tarif. 


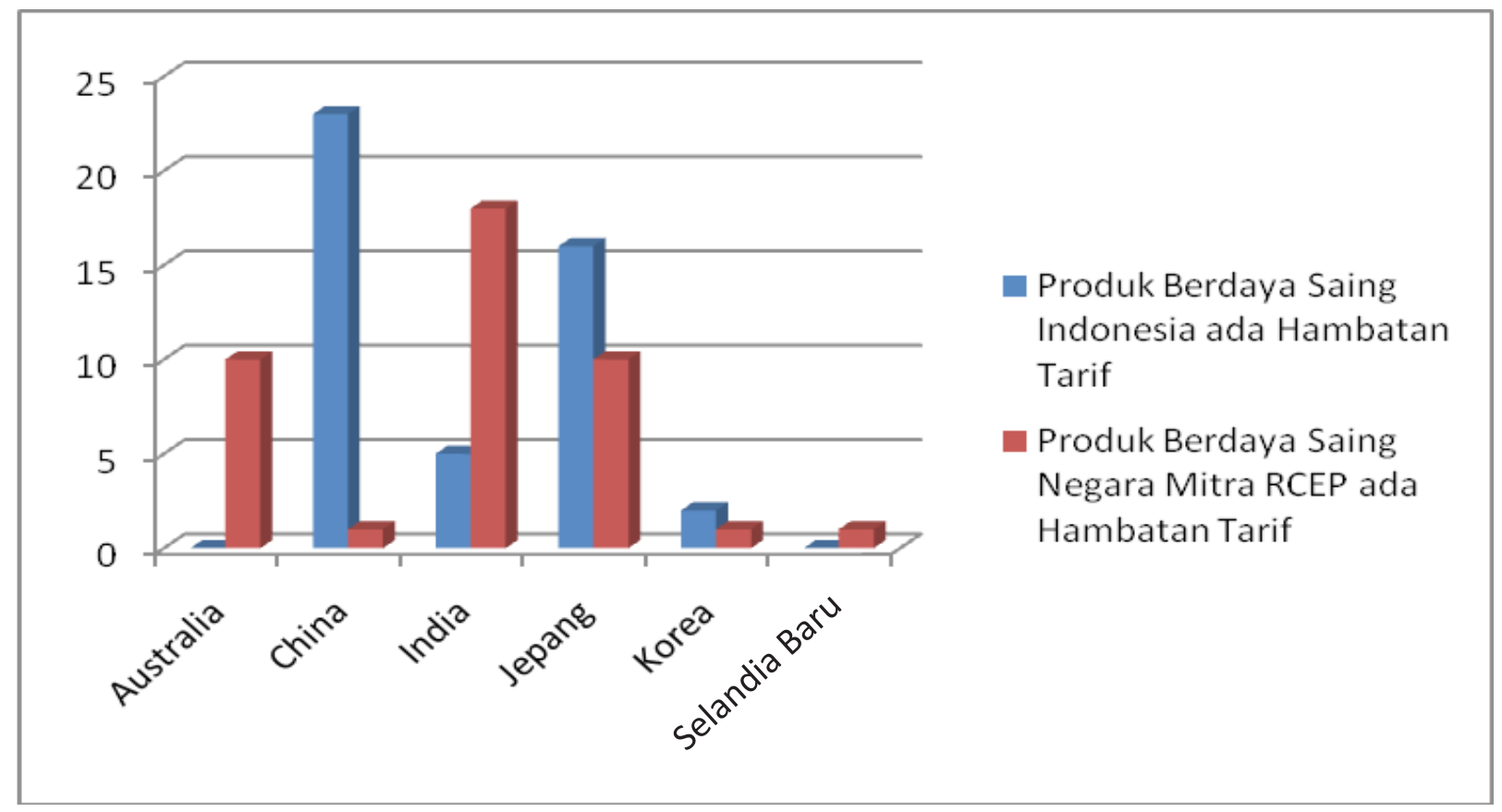

Gambar 3. Perbandingan Jumlah Produk Pangan Indonesia dan Negara Mitra RCEP Berdaya Saing yang ada Hambatan Tarif

Sumber : UN Comtrade, 2019 (diolah)

Mayoritas tarif produk pangan dari India yang masuk ke Indonesia sudah relatif rendah pada Tahun 2020. Produk pertanian yang memiliki kemungkinan menjadi permintaan India pada perjanjian RCEP adalah produk yang memiliki daya saing dan nilai ekspornya tinggi. Daging sapi tanpa tulang yang masih memiliki hambatan tarif di Indonesia sebesar 5 persen nilai impornya mencapai 283,6 juta USD pada tahun 2018. Impor daging sapi tanpa tulang dari India jumlahnya bahkan lebih banyak dibandingkan dengan impor daging sapi dari Australia yang jumlahnya 185,6 juta USD.

Hasil analisis CMS produk pangan Jepang di pasar Indonesia menunjukkan bahwa dari 48 produk pangan Jepang yang memiliki daya saing tinggi terdapat 10 produk pangan Jepang yang masih mendapat hambatan tarif di Indonesia. Produk tersebut diantaranya adalah Gula tebu/ bit (Rp790,00/kg), daging lembu (5 persen), jagung (5 persen), sake (Rp55.000,00/ltr). Jepang dapat mengajukan produk pangannya yang berdaya saing untuk diturunkan atau dihapuskan tarifnya oleh Indonesia. Hal yang menjadi pertimbangan adalah ada 16 produk pangan Indonesia yang memiliki daya saing di pasar Jepang masih ada hambatan tarif.
Berdasarkan hasil analisis CMS produk pangan Korea di pasar Indonesia, dari 34 produk pangan Korea yang memiliki daya saing terdapat 1 produk pangan Korea yang masih mendapat hambatan tarif di Indonesia. Produk tersebut adalah sake yang memiliki tarif impor sebesar Rp55.000,00/liter. Korea kemungkinan akan mengajukan produk pangan yang kurang berdaya saing untuk diturunkan atau dihapuskan tarifnya oleh Indonesia. Hal yang menjadi pertimbangan adalah ada 2 produk pangan Indonesia yang memiliki daya saing di pasar Korea masih ada hambatan tarif.

Hasil analisis CMS produk pangan Selandia Baru di pasar Indonesia menunjukkan bahwa dari 11 produk pangan Selandia Baru yang memiliki daya saing terdapat 1 produk pangan Selandia Baru yang masih mendapat hambatan tarif di Indonesia. Produk tersebut adalah kacang kedelai yang memiliki hambatan tarif sebesar 5 persen. Produk Selandia Baru yang memiliki daya saing kemungkinan diajukan untuk diturunkan atau dihapuskan tarifnya. Tetapi produk pangan Indonesia sudah dihapuskan semua tarifnya di Selandia Baru, sehingga tidak perlu mengajukan penghapusan tarif lagi. Oleh karena itu, apabila Selandia Baru mengajukan 
penurunan atau penghapusan tarif, Indonesia perlu menolaknya. Hal lain yang dapat dilakukan adalah mengajukan penghapusan hambatan non tarif di Selandia Baru atau mengajukan mengajukan kerja sama yang menguntungkan sektor pangan yang diperkirakan sebanding nilainya dengan permintaan penghapusan tarif produk Indonesia.

Adanya kerja sama RCEP merupakan peluang untuk menurunkan hambatan tarif produk pangan Indonesia berdaya saing tinggi. Berdasarkan gambar 3 terlihat bahwa produk pangan Indonesia yang berdaya saing dan memiliki hambatan tarif jumlahnya lebih banyak dibandingkan dengan China, Jepang, dan Korea. Hal ini menunjukkan bahwa Indonesia lebih banyak punya pilihan negoisasi penurunan tarif untuk produk bernilai daya saing positif.

Sebaliknya untuk produk pangan Australia, India, dan Selandia Baru yang berdaya saing, jumlah produk yang masih ada hambatan tarif di Indonesia lebih banyak dibandingkan jumlah produk pangan Indonesia yang berdaya saing tetapi masih ada hambatan tarif di negara tersebut. Hal ini menunjukkan bahwa Australia, India, dan Selandia Baru memiliki lebih banyak pilihan dalam negoisasi penurunan tarif untuk produk yang berdaya saing positif. Indonesia bahkan tidak memiliki pilihan produk yang dapat dimintakan penurunan tarifnya di Australia dan Selandia Baru.

Oleh karena itu, Indonesia harus lebih hati-hati dalam memberikan akses pasar produk pangan ke negara RCEP tersebut. Pemberian akses pasar dengan penurunan atau penghapusan tarif di Indonesia harus sebanding dengan manfaat yang diperoleh dari liberalisasi perdagangan RCEP.

Kerja sama RCEP merupakan kerja sama multi sektor. Produk yang masuk dalam perundingan untuk perdagangan bebas RCEP adalah semua produk seperti sektor perikanan, elektronik, mesin, pertambangan, dan sektor lainnya. Oleh karena itu, dalam proses negoisasi perundingan RCEP perlu adanya koordinasi sektor pangan dengan sektor lainnya. Contohnya apabila Indonesia mengajukan penurunan hambatan tarif daging unggas ke Jepang, Jepang menerima pengajuan penurunan tarif tersebut dengan syarat produk kendaraan dari Jepang juga diturunkan hambatan tarif masuknya ke Indonesia. Oleh karena itu, sektor pangan Indonesia perlu koordinasi dengan sektor industri kendaraan sehingga diperoleh kesepakatan yang saling menguntungkan.

\section{KESIMPULAN}

Berdasarkan hasil analisis yang telah dilakukan, terdapat beberapa kesimpulan sebagai berikut:

Produk pangan Indonesia yang memiliki daya saing berjumlah 41 produk di pasar Australia, 26 produk di China, 28 produk di India, 38 produk di Jepang, 28 produk di Korea, dan 36 produk di Selandia Baru. Produk tersebut sebagian besar adalah produk pangan olahan seperti roti, biskuit, mie instan, pasta, margarin, minyak nabati, dan makanan olahan dari sereal.

Produk pangan negara mitra RCEP yang memiliki daya saing di pasar Indonesia terdiri dari 60 produk Australia, 79 produk China, 39 produk India, 48 produk Jepang, 34 produk Korea, dan 11 produk Selandia Baru. Produk pangan negara mitra RCEP terdiri dari produk pangan olahan dan segar.

Posisi sektor pangan Indonesia dalam memanfaatkan kerjasama perdagangan RCEP adalah dengan mengusulkan penghapusan atau penurunan tarif produk pangan Indonesia yang berjumlah 23 produk di China, 5 produk di India, 16 produk di Jepang, dan 2 produk di Korea. Sedangkan peningkatan akses pasar produk pangan Indonesia di pasar Australia dan Selandia Baru adalah dengan usulan pengurangan hambatan non tarif, karena hambatan tarif di dua negara tersebut sudah tidak ada.

Posisi sektor pangan Indonesia yang masuk kategori perlu perlindungan tarif adalah beras dan gula, produk ini masih menerapkan kebijkan tarif di semua FTA dengan negara mitra RCEP. Kategori produk yang dapat ditawarkan untuk penghapusan tarif adalah produk pangan Indonesia yang sudah dihapuskan tarifnya di semua perjanjian FTA dengan negara mitra RCEP. Jumlah produk yang masuk kategori ini ada 260 produk. Kategori selanjutnya adalah produk yang masih menerapkan kebijakan tarif 
minimal untuk salah satu negara mitra RCEP.

Produk pangan negara mitra RCEP berdaya saing dan masih ada hambatan tarif impor di Indonesia jumlahnya 10 produk Australia, 1 produk China, 18 produk India, 10 produk Jepang, 1 produk Korea, dan 1 produk Selandia Baru. Indonesia harus lebih hati-hati dalam menghapuskan tarif untuk produk tersebut, karena akan berlaku untuk semua negara.

\section{UCAPAN TERIMA KASIH}

Penulis menyampaikan terima kasih dan penghargaan kepada Kementerian Pertanian yang sudah membantu pendanaan dan penyiapan bahan serta berbagai pihak yang telah membantu dalam penyiapan bahan dan sampai diterbitkannya naskah ini.

\section{DAFTAR PUSTAKA}

Azhari dan Widyastutik. 2016. Determinan dan Ekuivalen Tarif Jasa Finansial dan Asuransi Negara RCEP. Buletin Ilmiah Litbang Perdagangan. Vol.10 No.2:147-166.

Badan Pusat Statistik. 2018. Hasil Survei Pertanian Antar Sensus (Sutas) 2018. Badan Pusat Statistik. Jakarta.

Bustami, B.R., dan P. Hidayat. 2013. Analisis Daya Saing Produk Ekspor Provinsi Sumatra Utara. Jurnal Ekonomi dan Keuangan Vol.1 No,2: 5671.

Daryanto, A. 2009. Posisi Daya Saing Pertanian Indonesia dan Upaya Peningkatannya. Makalah disampaikan pada Seminar Nasional Peningkatan Daya Saing Agribisnis Berorientasi Kesejahteraan Petani. 14 Oktober. Bogor.

Juanda, B. 2001. Pertumbuhan Ekonomi dan Pergeseran Struktural dalam Industrialisasi di Indonesia: Pendekatan Model Dual Ekonomi. Laporan Penelitian Hibah Bersaing VII Perguruan Tinggi-Dikti-Institut Pertanian Bogor. Dikti. Jakarta..

Kementerian Pertanian. 2018. Statistik Pertanian 2018. Pusat Data dan Sistem Informasi Pertanian, Kementerian Pertanian Republik Indonesia. Jakarta.

Kementerian Perindustrian, 2018. RCEP Rugikan Sektor Jasa dan Manufaktur. http://www. kemenperin.go.id/artikel/8778/RCEP-RugikanSektor-Jasa-dan-Manufaktur. [Di akses 31 januari 2019].

Leamer and Stern. 1970. Quantitative International Economics. Aldine Publishing Company. Chicago.

Sekretariat Negara. 2007. UU no.17 Tahun 2007 Tentang Rencana Pembangunan Jangka
Panjang Nasional Tahun 2005-2025. Lembaran Negara RI Tahun 2007, No. 33. Sekretariat Negara. Jakarta.

Sekretariat Negara. 2009. UU no.41 Tahun 2009 Tentang Perlindungan Lahan Pertanian Pangan Berkelanjutan. Lembaran Negara RI Tahun 2009, No. 149. Sekretariat Negara. Jakarta.

Sekretariat Negara. 2012. UU no.18 Tahun 2012 tentang Pangan. Lembaran Negara RI Tahun 2012, No. 227. Sekretariat Negara. Jakarta.

Tatarer, O. 2004. The Exporr Performance Of The Turkish Manufacturing Industries With Respect to Selected Countries. PhD Thesis at Middle East Technical University Turkey.

\section{BIODATA PENULIS:}

Dadan Adi Nugraha dilahirkan di Kuningan, 25 Maret 1983. Penulis menyelesaikan pendidikan S1 di Program Studi Manajemen Agribisnis, Institut Pertanian Bogor tahun 2007, dan menempuh Pendidikan S2 pada Program Studi Agribisnis, Program Pascasarjana, Universitas Sebelas Maret Surakarta tahun 2015.

Minar Ferichani dilahirkan di Yogyakarta, 31 Maret 1967. Penulis menyelesaikan pendidikan S1 di Bidang IImu Peternakan, Universitas Gajah Mada tahun 1992, pendidikan S2 Bidang IImu Pertanian Universitas Gajah Mada tahun 1998, dan pendidikan S3 Bidang IImu Ekonomi Pertanian, Universitas Gajah Mada tahun 2007.

Joko Sutrisno dilahirkan di Yogyakarta, 24 Agustus 1967. Penulis menyelesaikan pendidikan S1 di Bidang IImu Sosial Ekonomi Pertanian, Universitas Sebelas Maret tahun 1991, pendidikan S2 Bidang Ilmu Pertanian Universitas Gajah Mada tahun 1998, dan pendidikan S3 Bidang IImu Pengelolaan Sumber Daya Alam dan Lingkungan, Institut Pertanian Bogor tahun 2011. 